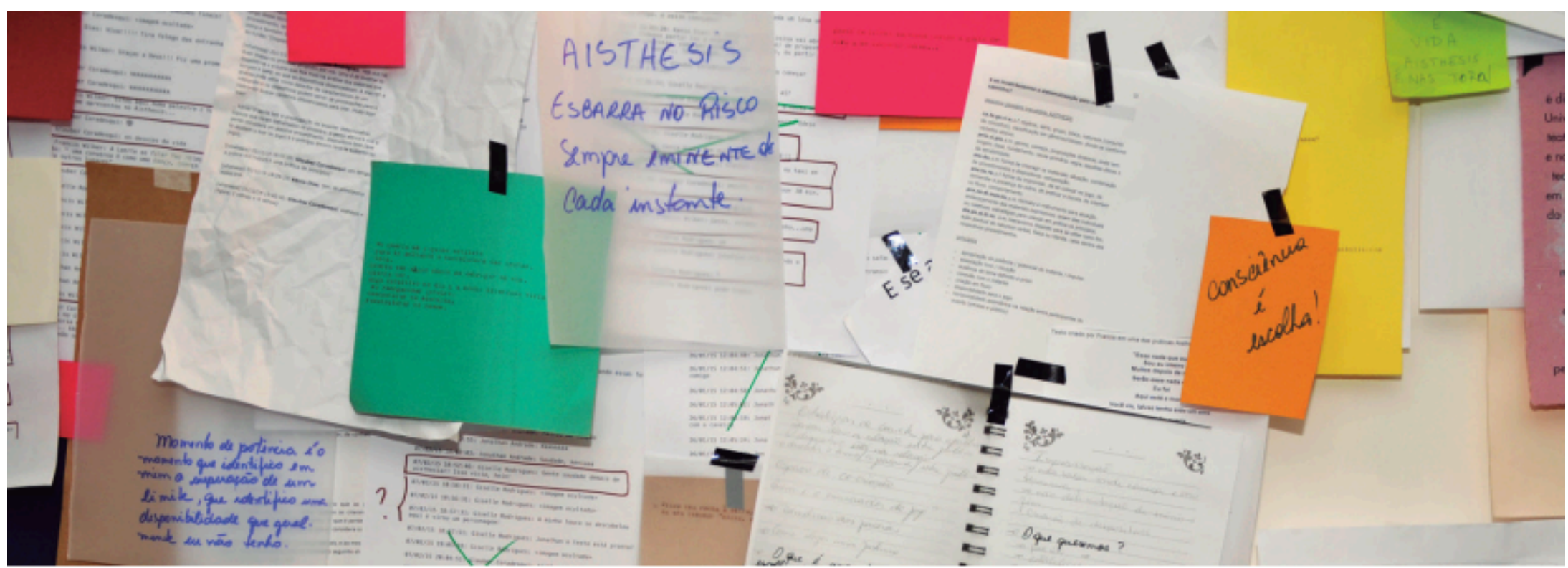

\title{
Exercício de apaixonamento da
}

\section{escrita como narrativa de Aisthesis ${ }^{1}$}

\section{POR GISELLE RODRIGUES}

1 Aisthesis - projeto de pesquisa sobre processo de criação em Artes Cênicas realizado em 2014/15 por um grupo de seis artistas. Os artistas participantes foram Édi Oliveira, Francis Wilker, Giselle Rodrigues, Glauber Coradesque, Kenia Dias e Jonathan Andrade, além do público. $O$ projeto conta com a colaboração da coreógrafa portuguesa Vera Mantero e do designer Luis Gustavo Meneguetti. 


\section{RESUMO: ESTE ENSAIO SE CONFIGURA COMO UM EXERCÍCIO DE ESCRITA PERFORMATIVA, QUE VISA EXPRESSAR UM BREVE RELATO DA PESQUISA EM ARTES CÊNICAS INTITULADA AISTHESIS, DA QUAL PARTICIPEI.}

Muitos textos, imagens, vídeos foram registrados no processo, do qual parte deles não foram compartilhados com o público. Ao revisitar este material, observo a riqueza de seus conteúdos revelados na precisão das gestualidades improvisadas dos participantes, na felicidade dos encontros, na denúncia de conflitos intimos, nas composiçōes cênicas e textuais aleatórias e despretensiosas que aconteceram sem que se desejasse, na brincadeira sensória com as palavras, nas conversas reflexivas. Quanto de filosofia se inscreveu ai? Quanto de sociologia se exercitou neste espaço criativo? Quanto de anatomia e psicologia não se impuseram no jogo dos corpos em relação? Quanto de arte e vida não se imbricou? Quanto de politica não se experimentou? Quanto de afeto emergiu? Uma beleza sem fim...
Este ensaio também parte de um desejo de aproximar a experiência da escrita à experiência vivenciada em Aisthesis, sem endurece-la, sem fazer desta somente discurso de comprovação e de afirmação do que foi gerado como conhecimento no próprio fazer, sensação que normalmente tenho ao elaborar um texto acadêmico. Em Aisthesis o corpo em relação era o lugar do acontecimento, da investigação, inquietação, curiosidade, dos conflitos, do devir em fluxo sem preocupação de construir sentidos, estabelecer ou encontrar lógicas. A criação se dava entre a explosão e a calmaria dos encontros, entre os vazios e caos instalados pela encenação dos instantes. Nesse sentido a apresentaçăo de alguns relatos escritos, divagações em poemas, reflexões sobre o processo e algumas imagens comporão o corpo deste ensaio, sem a preocupação de construir uma linearidade narrativa. É um exercício que fricciona palavras de um texto escrito discursivo, que tentam de alguma forma traduzir uma experiência, à apresentação, também como discurso, de imagens que emergem da prática. Será possível uma escrita que não distorça a comunicação da prática? (HASEMAN, 2015)

\section{PARA COMEÇAR DE ALGUM LUGAR}

Todas às vezes que tenho que escrever um texto começo me justificando, pois, escrever para mim, tem sido uma grande dificuldade. A justificativa se dá um pouco para me convencer da necessidade de escrever, que quase nunca está presente na minha vida. Talvez pelo medo de assumir a responsabilidade de uma exposição! Uma sensação paradoxal, já que o processo como artista também é exposição, um discurso do mundo por um olhar particular, do qual marca um posicionamento sobre as coisas. $\mathrm{A}$ justificativa é sintoma desse sentimento paradoxal, do medo da exposição de uma intimidade do pensamento na escrita, medo de revelar uma insegurança intima em relação a posicionamentos, que particularmente são tão mutáveis quanto meu próprio percurso artístico. $\mathrm{O}$ bloqueio da escrita quiçá seja também em função de uma autocrítica acentuada ou até por 
uma falta de atração de uma escrita que me solicita comparação, comprovação, resultado e forma. $O$ fato de ingressar num doutorado agudizou este entrave. Logicamente, que as dificuldades não são só minhas, e este conflito está especialmente presente para muitos artistas que se veem diante da tarefa de escrever sobre seus processos tendo que seguir regras e formatos especificos exigidos por moldes acadêmicos que se pautam predominantemente por parâmetros quantitativos com seus dados numéricos, e qualitativos, que se expressam em palavras, mas ainda traduzem números (HASEMAN: 2015). Como escrever um texto acadêmico que abarque a vivacidade, conflitos e prazeres de uma prática artística que tem como natureza deixar que a construção de algo se dê no processo de sua feitura, desprendido de medidas estabelecidas, de formatos padronizados, sem negar que eles existam, mas permitindo deslizar para fora das convenções? A escrita me denuncia e me trai ao mesmo tempo, porque quando escrevo não consigo me colocar ao lado, não consigo me distanciar daquilo que escrevo e "o eu se fala na intimidade e se põe a nu, à disposiçăo do julgamento dos leitores." (ALBERTI, 1991: 74). Ao mesmo tempo, sinto que quando escrevo tentando seguir formatos, algo se enrijece em mim, e as palavras não parecem suficientes para dizer sobre um processo.

Como professora universitária esperam de mim "fabricar o discurso escrito". Entretanto como artista-educadora vejo as próprias obras/ processos de criação como um percurso do discurso, vivido, pensado, refletido, muitas vezes apresentando reflexőes contundentes, embora fora dos moldes acadêmicos. Compartilho com Marcos Buti (2005) o incômodo de constatar que produtividade acadêmica é sinônimo de "fazer projetos artísticos com metodologia científica, publicar textos, dar palestras, participar de congressos, fazer relatórios, tudo o que possa ser facilmente contado e qualificado como intelectual e reflexivo sem deixar margem a dúvidas" (BUTI, 2005:92), reduzindo a realizaçăo artística, ou mesmo os processos artísticos em esquemas conceituais sem considerar a complexidade que isso envolve, e pior ainda, sem considerar a arte como forma de conhecimento. Talvez Buti esteja certo ao afirmar que "a Arte está presente (ou é tolerada) na Universidade graças a um equívoco" (2005:90) de acharem que métodos científicos de pesquisa sejam aplicáveis as Artes. Além disso, os ambientes acadêmicos muitas vezes impõem um ritmo de produtividade que não combina com as demandas da criação artística, que necessitam em seus processos de pesquisa/criação de espaços de tempo dilatados, sem a pressão de cumprimentos de prazos e formatos especificos. Sem querer aqui abrir esta discussão, embora entenda sua importância, quero me ater a escrita deste ensaio, sem preocupação acadêmica demasiada, como um exercício mais livre e desapegado, compromissado com a poesia de um processo artístico. Aqui é mesmo um exercício de narrar sobre um projeto de pesquisa que suscitou muitas reflexões sobre o fazer cênico, perpassando por diversos temas como o trabalho de formação e de amadurecimento de artistas cênicos a partir de seu próprio fazer, da sua busca por soluções de problemas que emergiram da prática. Além disso, de observar o desenvolvimento e 
aprimoramento de uma sensibilidade de escuta para a experiência da relação com o público e a inquietação no trabalho de aguçar a percepção dos possíveis caminhos que as improvisações em tempo real com a cena ofereciam. De também entender ao longo do percurso, o processo como obra, que năo se limitou a um resultado final, mas a vários pequenos momentos cênicos poéticos. Além de tantas outras temáticas que atravessaram esse percurso, a dimensão mais sensível talvez, que ressalta do processo de criação, é a dos afetos. Como esta prática improvisacional de Aisthesis lidou fortemente com os afetos, com as relaçōes dentro de um coletivo. Cada texto escrito, cada imagem capturada tanto em fotos como em vídeos, assim como os áudios gravados nos dão a dimensão dos saberes ali construídos, embora escrever sobre esses saberes e uma gama de sensaçōes e de impressões sobre o processo, parece que nunca me satisfaz. Só as palavras, não conseguem alcançar a dimensão da experiência vivida. Pelo menos é assim que sinto ao escrever sobre ele. Mas tentarei!

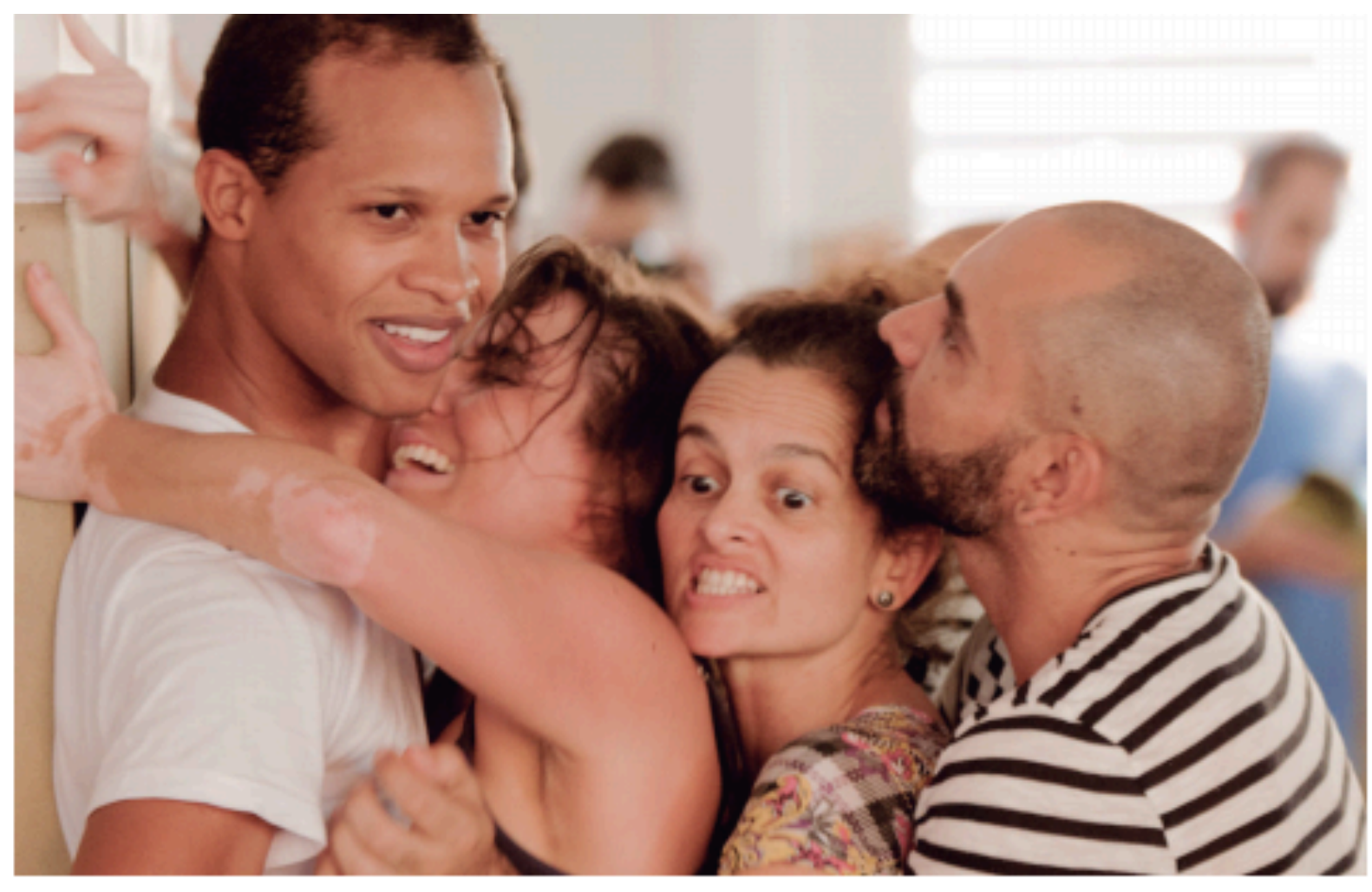

Rolland Barthes nos diz que "escrever é um abraço, é ser abraçado" (BARTHES apud COTT, 2015:posição 40), e que cada ideia é uma ideia que se expande. Ele diz ainda que "cada escritor tem seu modo de se haver com a língua"(2007), como uma dança/luta, em que "os escritos mais desenvoltos, mais harmoniosos [...] resultam de afrontamentos e esquivas em dança" e que "na escritura, como na dança, a facilidade, a espontaneidade, o natural, são efeitos de um trabalho" (2007). De fato, escrever para mim tem sido esse afrontamento, mas uma dança ainda pouco fluida, que se esbarra 
a todo momento num obstáculo. Essa dança ainda não é a dança que me faz sentir o corpo em fluxo, o pulsar das veias e a consciência da respiração, essa dança que me faz entender o espaço quando me lanço nele, que abre a atençăo de todos os sentidos ao mesmo tempo para sentir o tempo. Aqui é a tentativa de dançar essa dança proposta por Barthes. Para Barthes "a linguagem humana é sem exterior, é um lugar fechado" (BARTHES, 2007:14), a língua é opressora que nos deixa presos, subjugados ao poder, e para ele, uma possibilidade de trapacear este poder está na prática de escrever, na literatura, e "é no interior da língua que a língua será combatida, desviada." (BARTHES, 2007: 15)

\section{A escritura é uma enunciação que expõe o lugar e a energia do sujeito. (BARTHES, 2007)}

\section{Vamos a ela!}

\section{AISTHESIANDO COM PALAVRAS OS RASTROS DA TRAJETÓRIA AISTHESIS}

Escrever é desapegar-se um pouco de si para abrir-se ao outro. É ato político e maneira de ocupar o sensivel (RANCIÈRE, 1995:07). Deixo que o outro pense a própria história, por meio das minhas palavras.

Deixo que o outro crie sua própria narrativa, outras paisagens, outros mundos. Logo, essa escrita, ao chegar no outro, será outra coisa. Como não terei mais o domínio sobre ela, não quero me preocupar com ela. Só pretendo que ela flua. Ela precisa fluir. Então, aqui é uma tentativa de fluir uma escrita sobre a criação em mim, e também sobre Aisthesis. Aisthesis é fluxo coletivo, é encontro, é liberdade de açăo, improvisação atemática, sem roteiros preestabelecidos, sem territórios

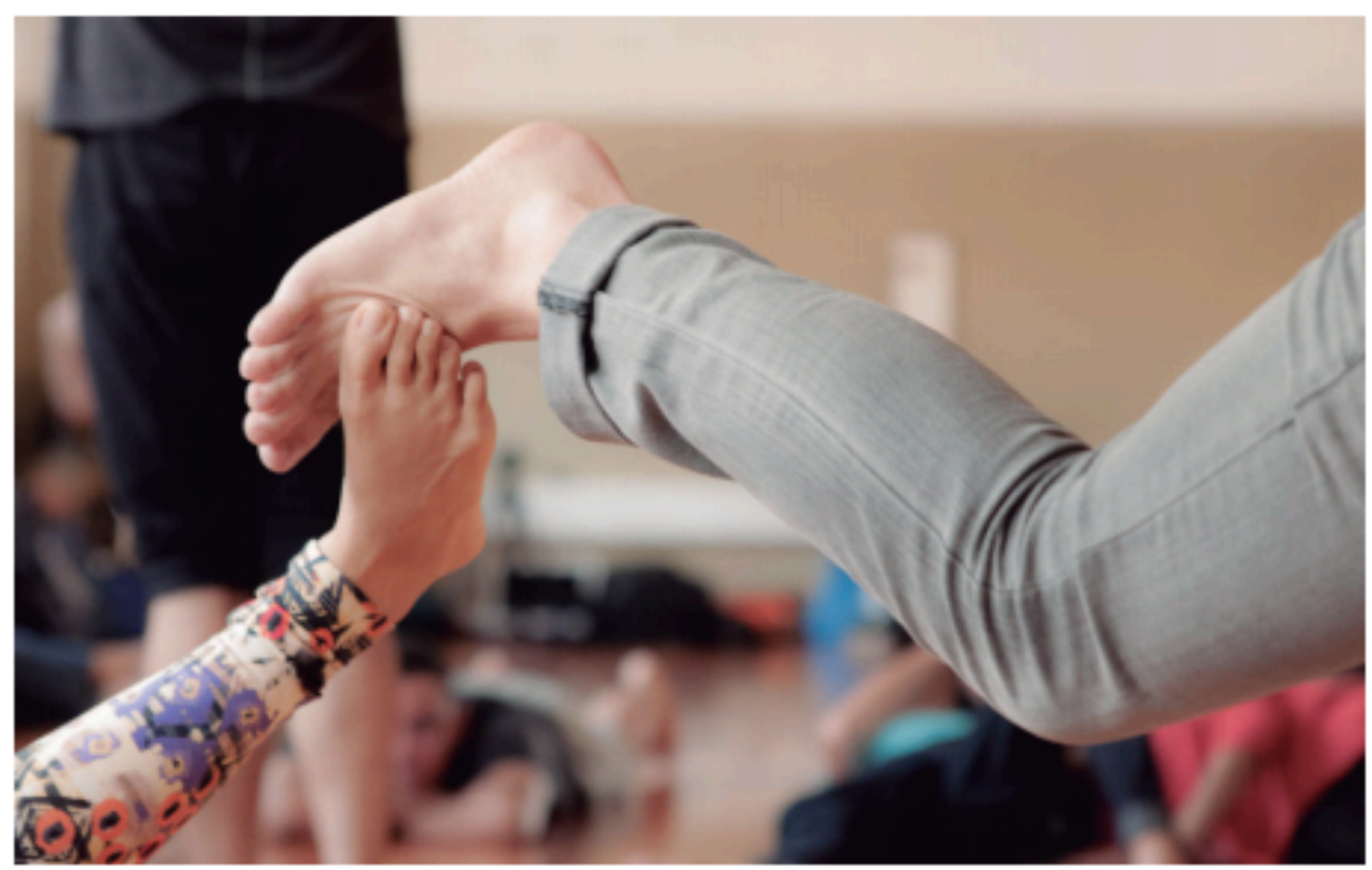


demarcados. Poderá ser essa escrita uma reflexão? Pode ser que eu narre, pode ser que eu descreva, pode ser que eu devaneie na memória e modifique o que já passou, afinal "o escritor no processo de produção da narrativa, se move continuamente entre o que é e o que poderia ser" (ALBERTI,1991:01). Deslizarei! Pode ser que eu analise, pode ser que haja alguma teoria pessoal que tente dialogar com as teorias dos pensantes de oficio, pode ser pura blasfêmia e pode ser que essa blasfêmia diga algumas verdades sobre mim. Pode ser que sirva para alguém, mas pode ser que não sirva também. Se ela será válida? A Luisa (a Günther) vai dizer....Quero mesmo é buscar o impulso da mão, para que ela vá sozinha, tocando os teclados, sem que eu me dê conta quais palavras exatamente ela constrói. Me interessa o fluxo, me interessa dar vazão a uma inteligência que não sei que tenho. Tantas coisas acumuladas, devem uma hora sair por aqui, sem que eu formule demasiadamente sobre elas. Assim continuo a aisthesis, como um prolongamento de minha pesquisa Aisthesis que se guia pela prática (HASEMAN:2015). Então seguirei aisthesiando. No livro da Bia, a MEDEIROS (2005), está dito que aisthesis é palavra grega que nos diz: é mais pelos sentidos, pelas sensaçōes, do que pela elucidação, explicação. Sente! Sente! Na pele, no afeto da sonoridade escutada, no cheiro das coisas, na beleza da paisagem de um rosto alcançado pelos olhos, na sensação dos pés descalços em pisos frios. Perceber pelos sentidos. Aisthesis significa "um estar aberto ao mundo, aberto ao sensivel do/no mundo e deixarse contaminar (MEDEIROS, 2005:13). Opto por escrever com a fonte Calibri, por ser mais arrendondada. Quem sabe, escrever à mão fosse melhor! Daí sentiria verdadeiramente a escrita como prolongamento de meu corpo, "uma relação da mão que traça linhas ou signos com o corpo que ela prolonga" (RANCIĖRE, 1995:07). Será que assim pode-se chegar a uma tese? Ah! Desculpa! Esqueci que se dá respiro entre uma linha e outra. Um respiro medido milimetricamente, para que os olhos possam varrer as linhas, palavras, letras com mais espaço. 1,5 entre elas? Segue então uma tomada de fôlego.

\section{Respira para continuar!}

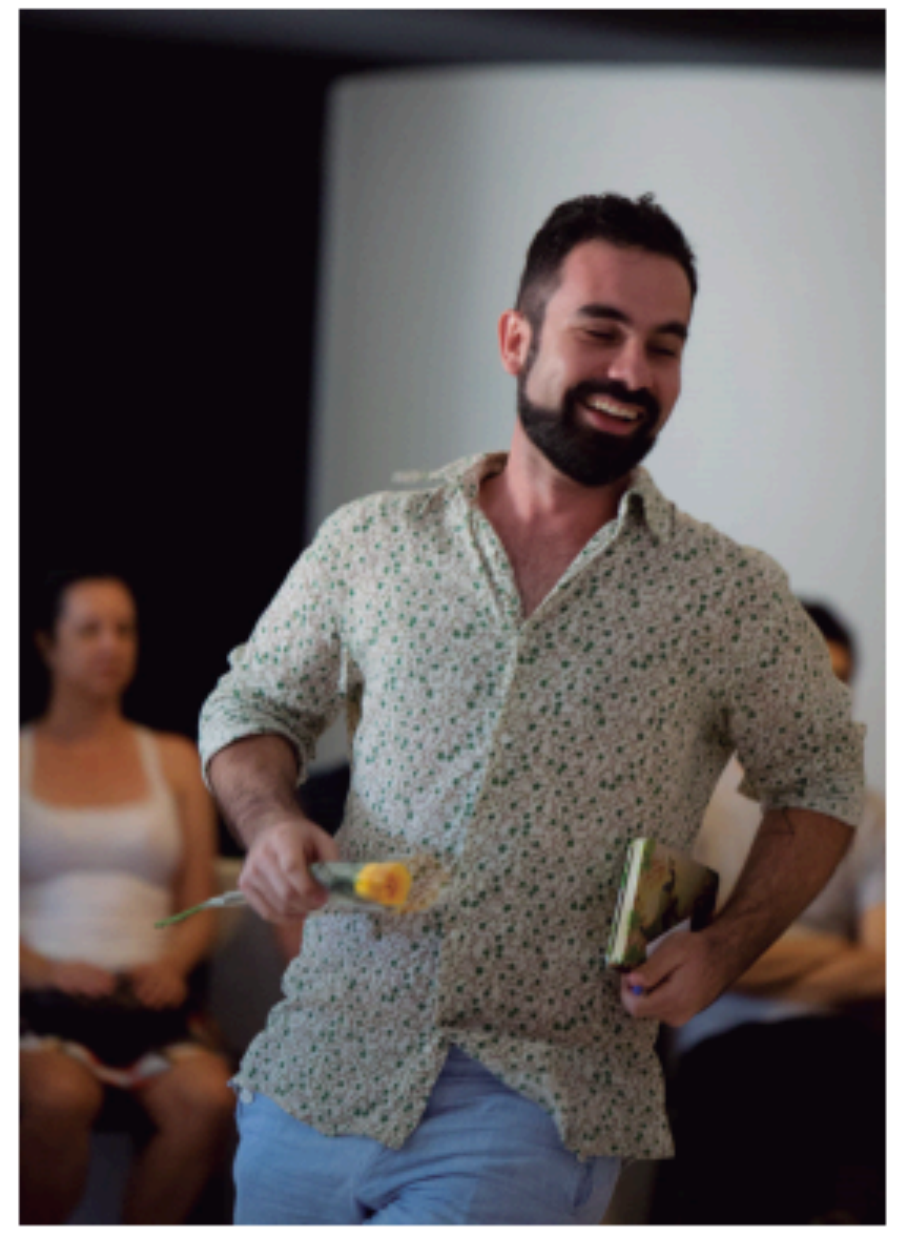


O que aqui precisa ser dito? Sempre tenho a sensação que nada mais precisa ser dito. Mas me dizem que apesar de tudo que já é dito, somente você saberá dizer o que você precisa dizer. Que o que interessa năo é exatamente o que você diz, já que tudo está dito, mas o como você diz, qual é seu olhar sobre o que já está dito, qual o seu olhar sobre o mundo. Mas escrever livremente, devaneando de olhos abertos (BACHELAR, 2009) sobre as experiências é uma coisa. Já escrever buscando DELIBERADAMENTE as conexões teóricas que possam alimentar ou mesmo reforçar o pensamento que se deu em forma de movimento, de ação, de experiência, ainda me é pouco natural! Exige uma luta interna, um afrontamento contínuo, uma resistência para năo perder o fluxo, a maciez de uma sensação de um maravilhamento, um apaixonamento de um impulso. Esse impulso sentido em AISTHESIS.

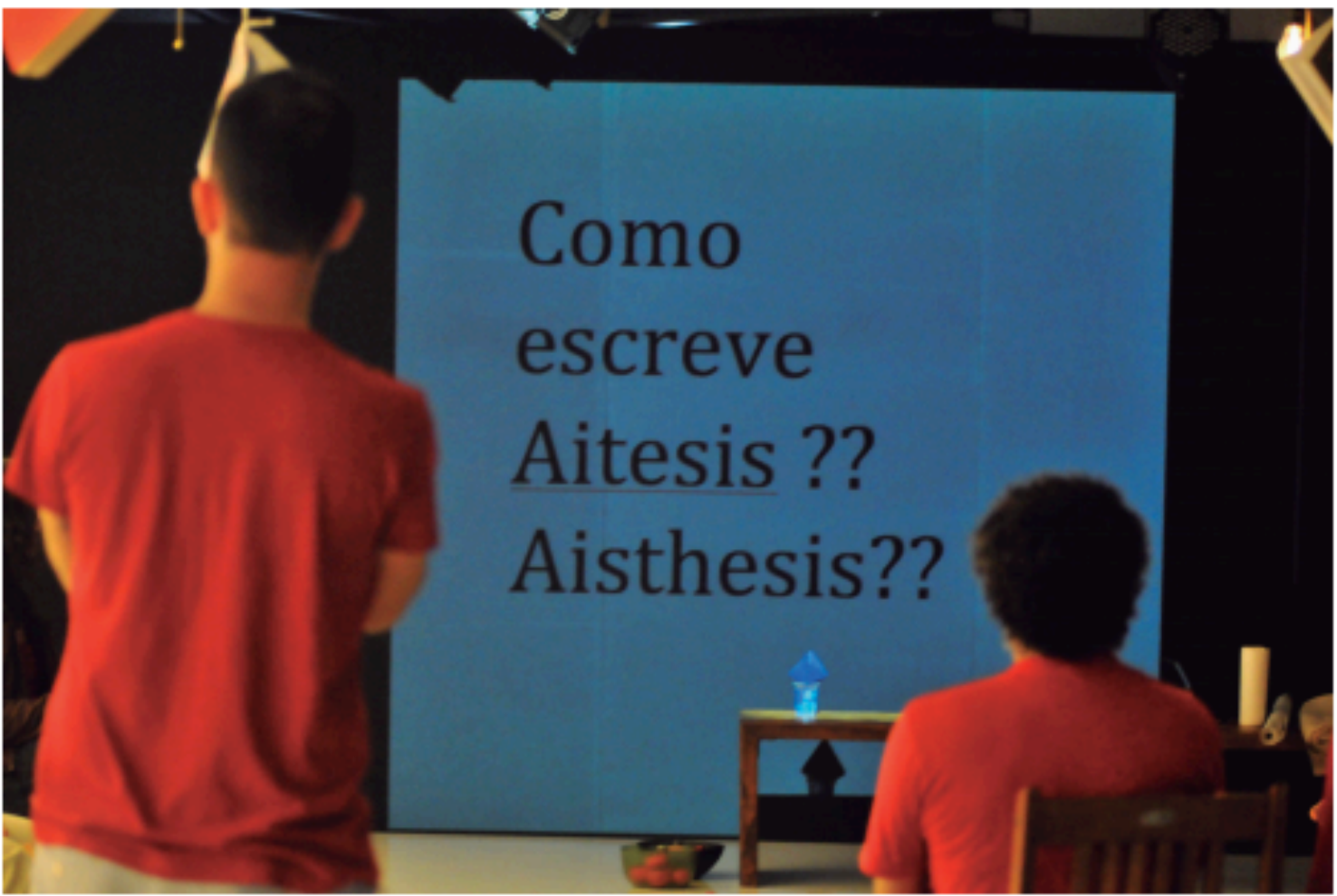

\section{VAMOS FALAR DE AISTESE? AISTESI? AISTHESIS?}

Fuçar, chafurdar, perfurar, aprofundar, se enfiar no buraco para ver o que tem embaixo! Cava, cava, que disseram que ai tem coisa. Qual coisa? Vou achar o estomago? Vou penetrar no pâncreas que não para de dar sinais de vida?" A dor é sinal de vida. O projeto me possibilitou dar uma mirada em meus rastros artísticos e me dar conta do interesse sempre presente em meus processos criativos pelo espaço do sensível que a arte

1 Didrio de bordo Giselle Rodrigues 2014-2015 
METAgraphias: letra D de dropbox (das derivas dançantes) v.2 n.1 marçol2017 Exercício de apaixonamento da escrita como narrativa de Aisthesis•Giselle Rodrigues (gisellerbrito@gmail.com)

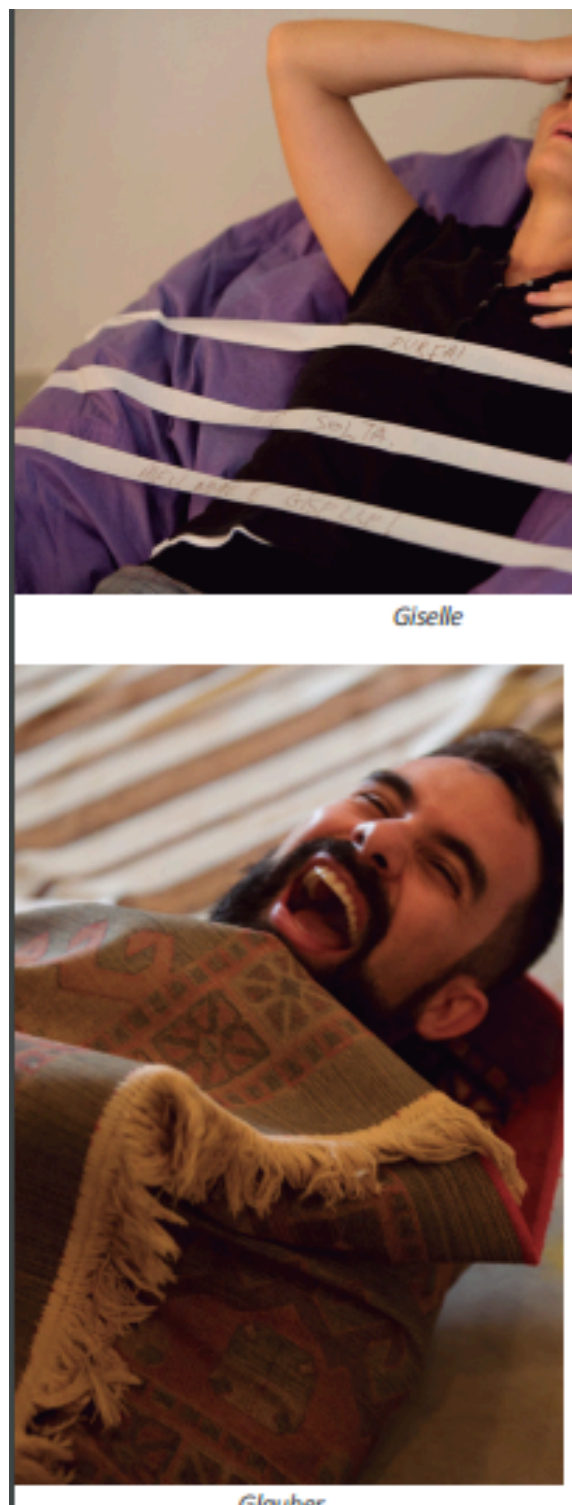

Glouber

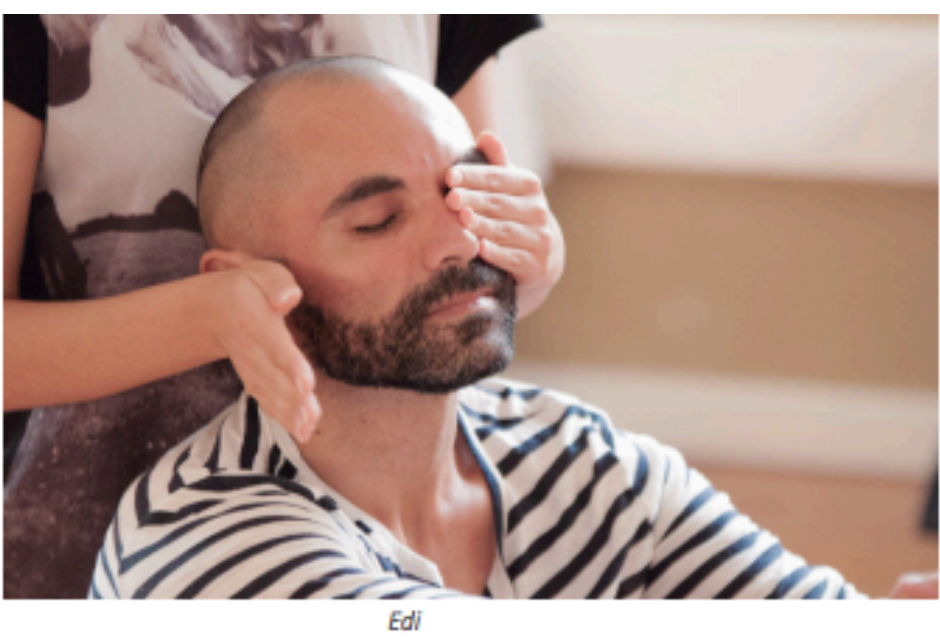

Edi

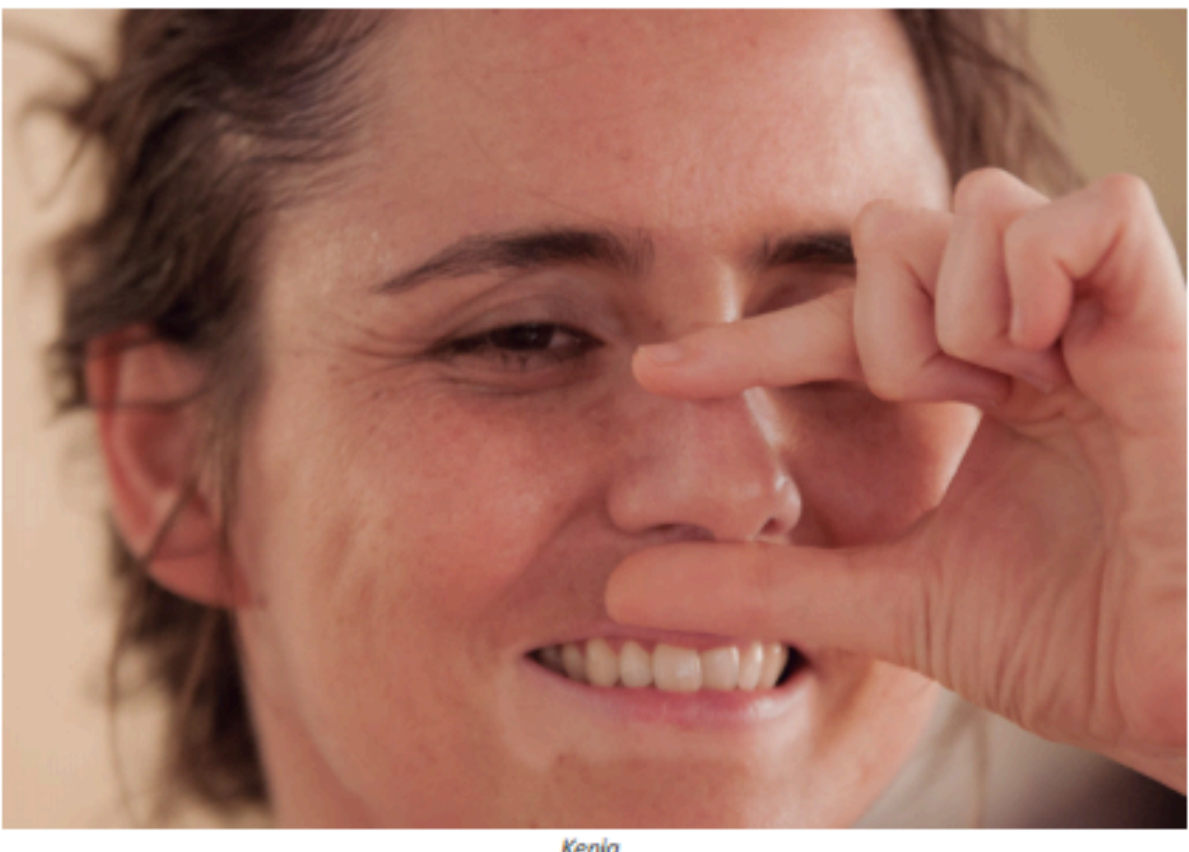

Kenio
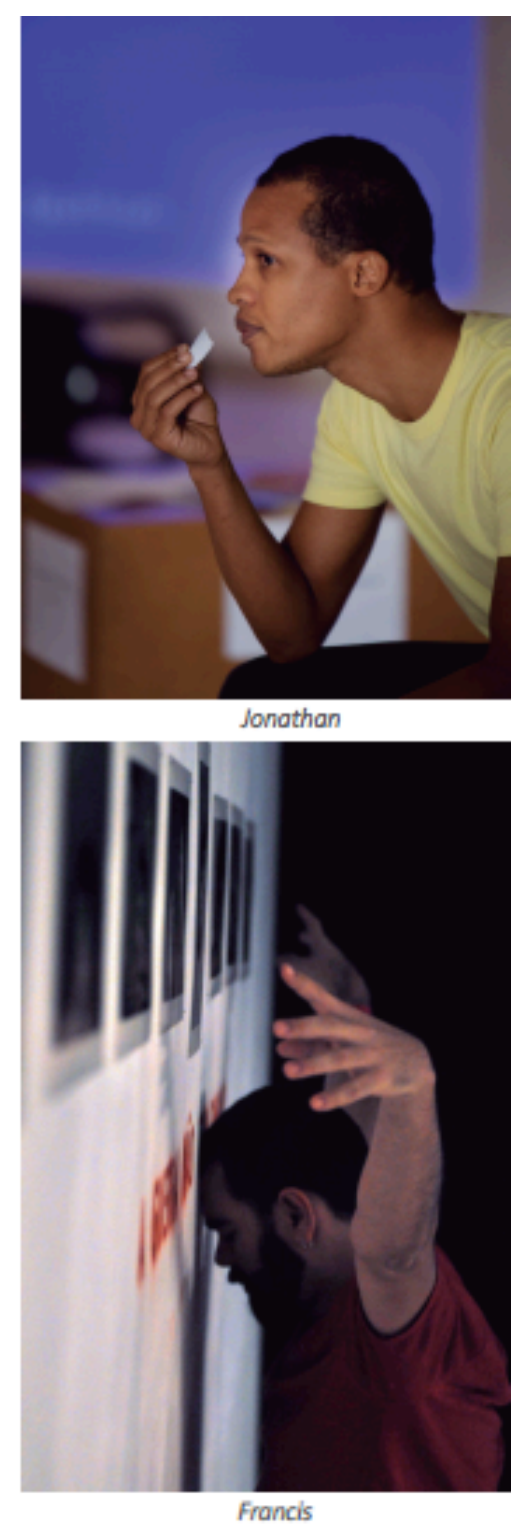


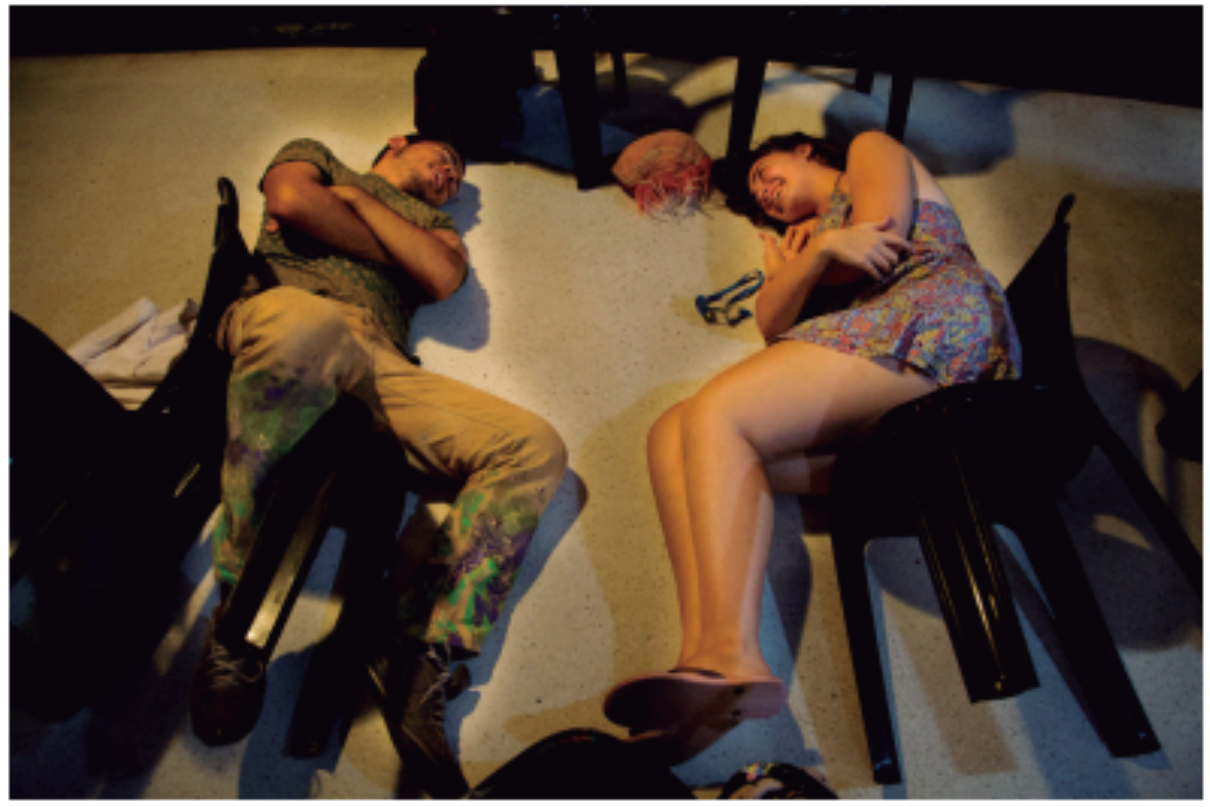

promove e sobre a percepção desses espaços no corpo e nas relações. Após vários experimentos dentro do projeto, observo que meu maior foco até então está no assunto sobre a percepção e sensaçס̃es no contexto do trabalho do ator/ bailarino/atuante cênico. Este interesse vem da curiosidade para entender $\mathrm{e}$ buscar caminhos que ampliem nossa capacidade de escuta, de sensibilização corporal, de atenção às coisas do mundo e as relações que se dão entre essas coisas e o corpo, e de como essa sensibilização, esse trabalho sobre atenção e escuta do atuante cênico interferem sobremaneira no percurso criativo e no momento da atuação. Este interesse pode parecer um tanto quanto voltado à psicologia humana, e talvez seja, por achar que o trabalho sobre a percepção e o sensivel esbarra sempre no como a pessoa lida com as coisas, sua visão de mundo e sua visão artistica.
"Entro em Aisthesis por um desejo de troca, um desejo de encontro, desejo de ser questionada, de fissurar minhas certezas, de experimentar abismos. Então, em 2014, me alio a mais cinco artistas' para poetizar com eles o espaço cênico em encenações do instante'. E não só com eles, mas também com o "público" que esteve presente continuamente no processo/obra. E então, Aisthesis começa a torcer meus paradigmas, meu corpo e minha lingua. Formatos, preconceitos, a compreensão de obra como resultado, .....tudo torce! Oscila entre as possibilidades de confirmar, negar, nutrir, surpreender hábitos da criação, torce os caminhos de processo que continuam ressoando na minha prática."

Os artistas participantes foram Edi Oliveira, Francis Wilker, Giselle Rodriques, Glauber Coradesque, Kenio Dias e Jonathan Andrade, além do público. $O$ projeto conta com a colaboraçäo da corégrafa portuguesa Vera Mantero e do designer Luis Gustavo Meneguetti.

2 Encenaçס̃o do Instante fol a melhor expressolo que encontramos para dizer sobre nossa prótica. Ela se define como uma prótica cếnica improvisacional, que mescla dança, teatro performativo, leitura de textos dentre outras linguagens. $E$ atemática e realizada sem roteiros elaborados previamente. Seu mote se pauta pelo encontro, com as coisas e com os outros, e o que deles emerge. $O$ encontro e o que emerge dele é potencializador da criaçâo cênica do instante. 
METAgraphias: letra D de dropbox (das derivas dançantes) v.2 n.1 marçol2017 Exercício de apaixonamento da escrita como narrativa de Aisthesis • Giselle Rodrigues (gisellerbrito@gmail.com)
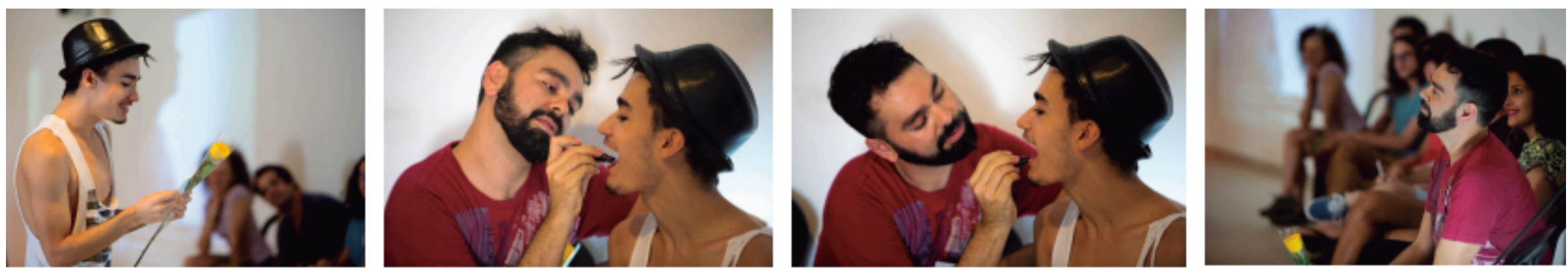

\section{Em AISTHESIS acontece \\ Diálogo de diferenças \\ Escuta de impulso}

Trânsito de zonas de especificidade pessoal

A palavra sem se preocupar com a semântica Retirada de referência

Ruído e pausa

Incidências e reincidências

$O$ inconsciente vomitado 
"Ela entrou na sala e não sabia o que fazer, onde sentar. Havia no espaço várias cadeiras amontoadas e espalhadas aleatoriamente. Será que podia pegar uma para se sentar? Ficou ali no canto, observando o que a maioria das pessoas faziam para então copiar. Deveria me sentar onde a cadeira estava situada? Ou poderia movê-la para outro lugar? Não sabia! Melhor esperar o que acontece! Daí, aconteceu!"
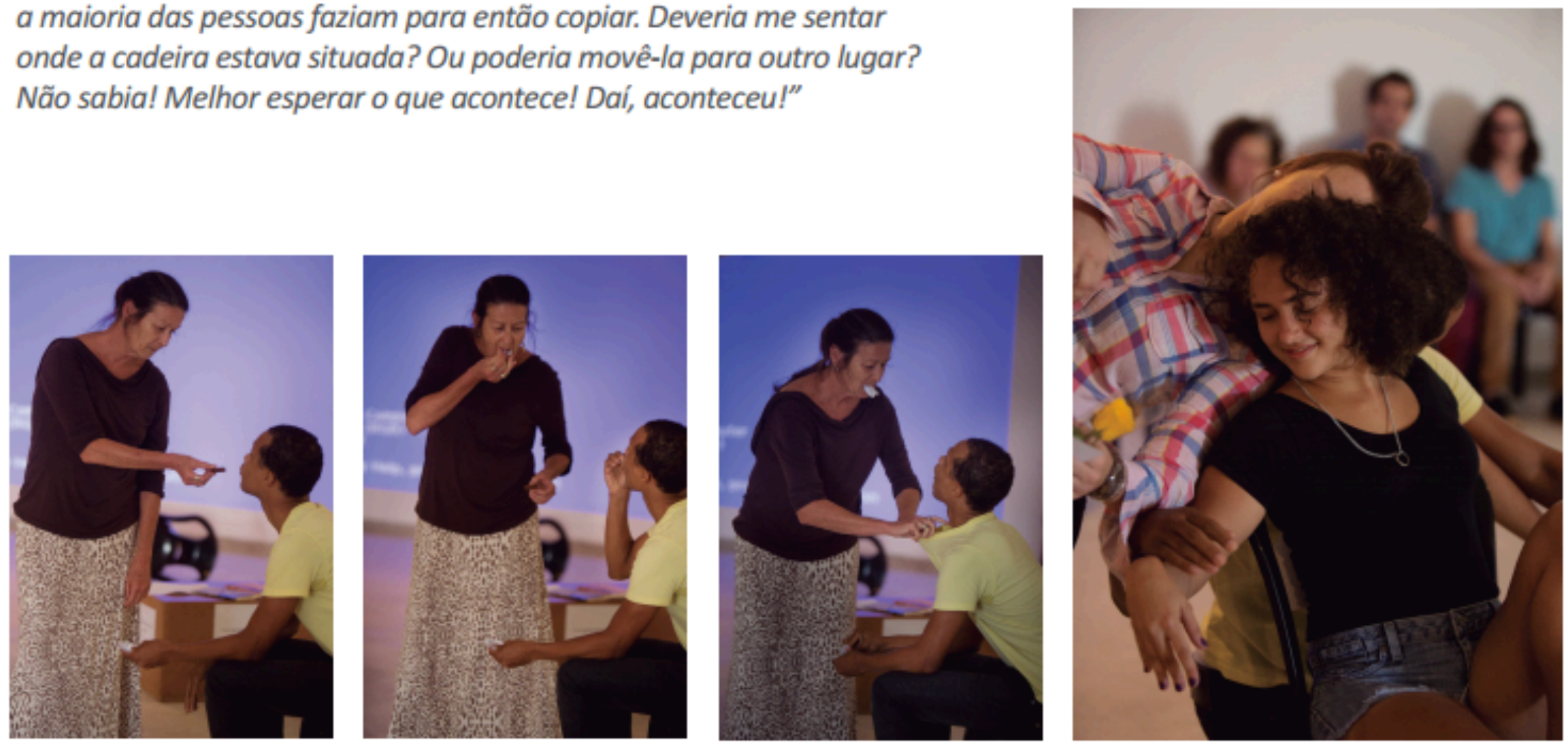


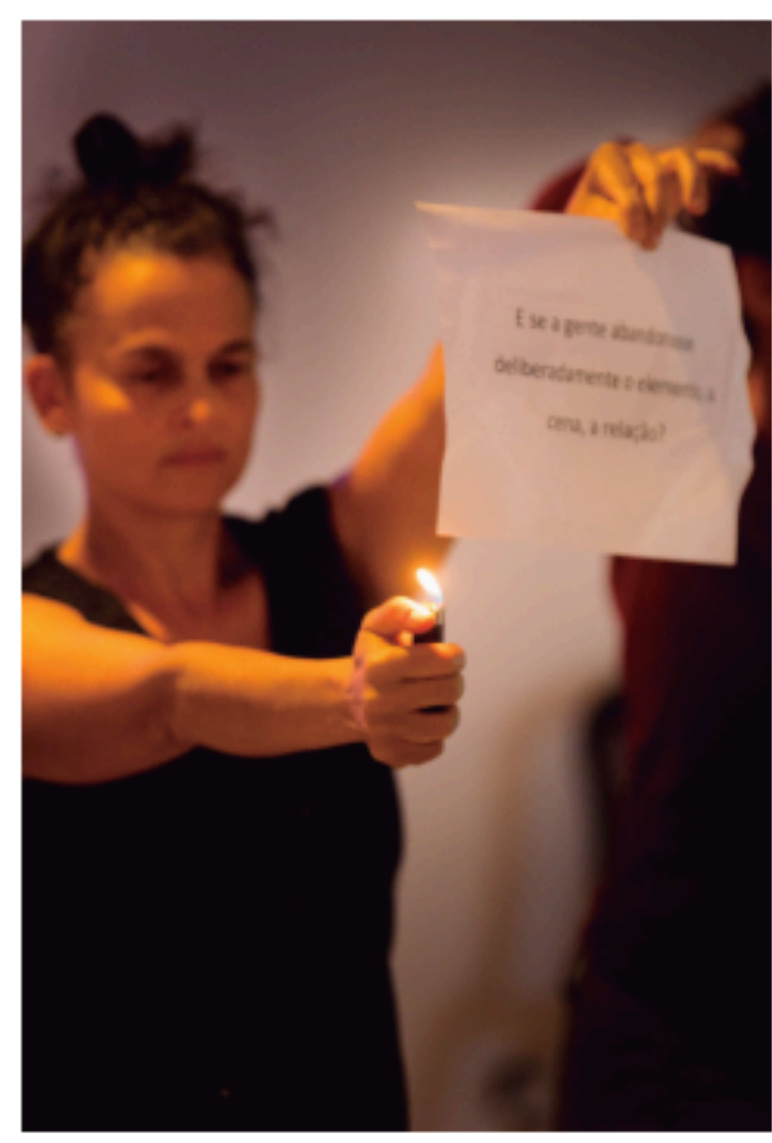

O comum com o outro está no campo do que partilhamos e nos engajamos. Quando se entra em Aisthesis almeja-se que todos estejam na mesma situação de criação, artista e público, e que possam atuar como performers do instante, se expressando como e quando quiserem. $O$ espectador pode assumir o papel que desejar e no momento que achar necessário, oscilando entre observador e performer, assim como os artistas e ... ela é uma performar sem querer performar.... ela entende que o fato de estar mais familiarizada com as ferramentas artísticas que possui, do que aquele que a olha, não garante um surpreendimento criativo, e fazer melhor uso delas só porque as possui, nem sempre é a solução. Essa vantagem talvez só demonstre a necessidade de poder sobre o outro, não garante o gozo criativo, e dificulta o fluxo das experiências. Retirar a valoraç̃̃o em relação ao que se diferencia de si, entender o sagrado não como um patamar acima, mas dentro das coisas cotidianas, se misturar e fazer emergir focos de concentração nos "estados de sagrado" é abrir uma disponibilidade para o fluxo da criação. É bom retirar o caráter solene que muitas vezes ocorre em situação de atuaçăo, em que o artista se torna o centro das atençōes, o "protagonista especial", o responsável por manter a atenção do público. A solenidade pode levar o artista performer a adotar uma atitude impositiva para manter o público sobre seu domínio. Em Aisthesis percebeu-se que era necessário desapropriar-se desse protagonismo de poder, desmistificar o lugar do artista como espaço sagrado, aceitando a simplicidade, dando vazão à poesia da cotidianidade. Quiçá essa simplicidade seja o ingrediente que atraia o público para participar do jogo. Adotar um sentimento de despretensão em relação à situação talvez ajude no fluxo dos afetos. Nesta dinâmica, dilui-se a fronteira espacial que delimita os campos de atuação de público e do artista, pois não existe mais o território exclusivo do artista, o espaço total torna-se arena de jogo para todos. 


\section{Comentário sobre um dos experimentos:}

Perdemos a sensibilidade da escuta, de deixar as situaçōes se instalar, pois a todo o momento propomos coisas novas, mudamos. Sugiro que prestemos atenção ao impulso, ao desejo momentâneo/instantâneo. Economizar. Abrir-se para a percepção mais aguçada das oportunidades que surgem e seus possiveis desdobramentos, à percepção da necessidade do corpo, do impulso, do espaço e do tempo.

Eu percebo para aproveitar, para continuar algo que foil lançado no espaço. Quando envaidece, para de funcionar. Para de comunicar. Fica impositivo, você força para o outro uma presença sua, uma autoafirmação. Será que isso é uma qualidade do momento? Mas também, fico pensando se esgotar esta imposiçåo faz surtir algum efeito positivo, ou năo!?

\section{AISTHESIS parece buscar uma}

dessacralização da atuação, ou do performer "empoderado". Não há sagrado! Há mistura! Há oscilaçăo! 0 ator/performer atuante vai buscar a oscilação entre estar desarmado deste "empoderamento", deste estado de sacralizaçăo de seu material artístico/ expressivo e trabalhar em si um estado de proximidade com o cotidiano a sua volta, sem necessariamente perder sua consistência. Meu deus! O que seria essa consistência? Ai, as palavras!

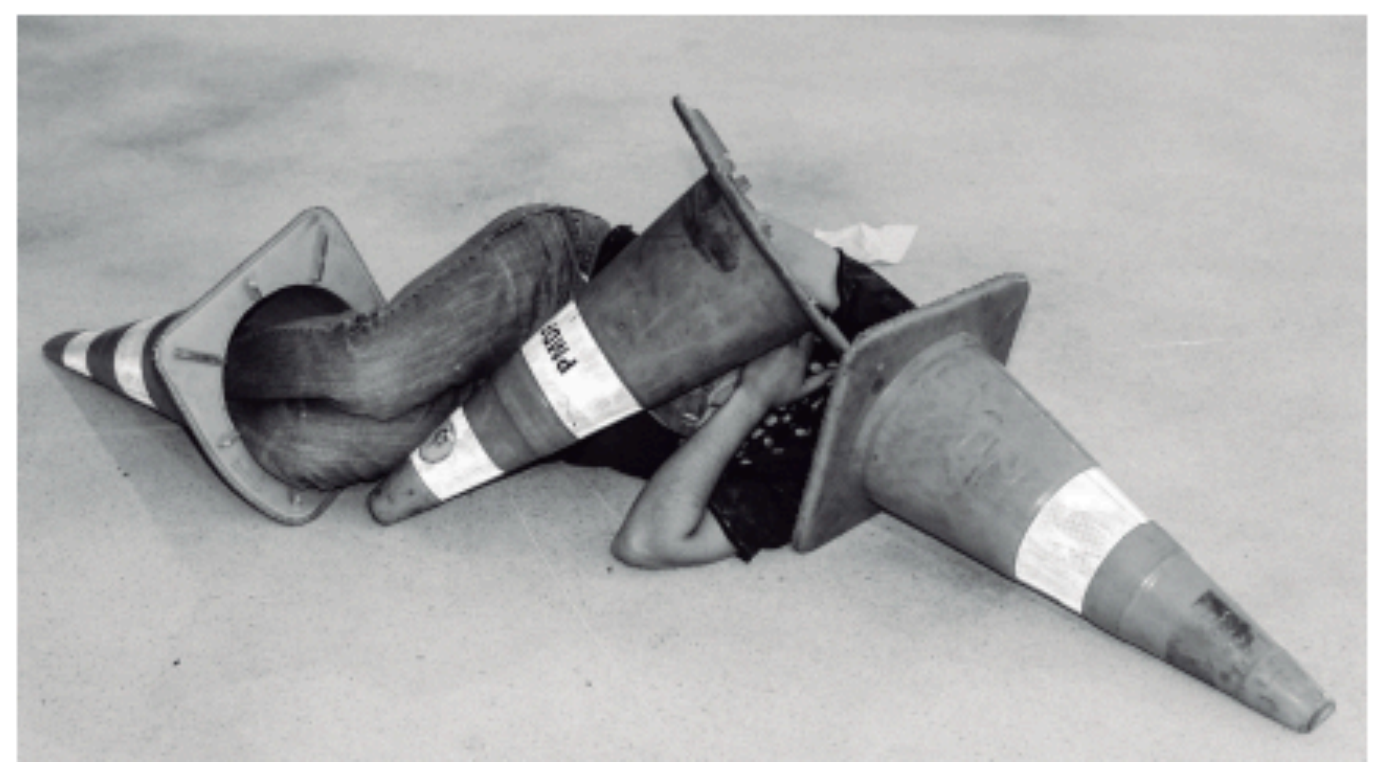

Seria seu estado de presença? Sua energia de ação em descanso? A consistência não tem a ver com a verdade necessariamente. Mas o grau de vivência e de experiência sobre aquilo. Ser consistente é o sujeito que comunica de forma "eficaz" = amor. É entender que o outro pode aproveitar sua proposição e a transformar, pois ela o afeta, sugere uma transformação. Ui! Que viagem! 
Em Aisthesis se é autor, sem se ser, pois é o coletivo que autora, ou seja, que cria, "que traz alguma coisa a mais." (VIELA in ALBERTI, 1998:03). Cada texto criado, cada ideia lançada, cada gesto realizado, não é mais meu.

157,158 , esses números penetram minha pele, nesse corpo, que estendido no chão, a mirar o teto, sem pretensão de vontade, vagueia entre o que parece ilusão, sensação que atravessa fortemente cada sentido, e a realidade, que por vezes, parece se colocar paralela ao que o desejo me oferece. A tábua corrida, e a madeira áspera a roçar no tecido da roupa e no tecido pele, o cheiro de ar escondido e velho. A percepção das sombras como abismos da luz. Uma tontura, ou quase uma tontura, que causa um êxtase interminável e prazeroso.

Aquele som também me penetra e é, ao mesmo tempo, exalado pelos meus poros. E o tempo foi absorvido e experimentado. Durou. Dilatou-se! Eximplodiu-se! Dilatou também o espaço, no qual o corpo pensava estar habitando. $O$ corpo se deu conta de que é espaço com o tempo a correr-lhe as veias. Lá estão os números pintados na barra de ferro pendurada no teto. 157 , 158 e mais etc de números. $O$ corpo se deu conta de que é tempo com o espaço a moldar-lhe os gestos. Não sou mais eu! Como uma excitação dionisíaca, em que o corpoalma dialoga com outra natureza se confundindo com as imagens que cria, ele vibra em "protofenômeno dramático: ver-se a si próprio transformado diante de si mesmo e então atuar como se na realidade a pessoa tivesse entrado em outro corpo, em outra personagem. " (NIETZSCHE, 1992:60). Uma pulsão dionisiaca. "potência de pensamento que habita antes do pensamento, sem o conhecimento do pensamento" (Jacques Rancière - Existe uma estética Deleuzeana?, p 505) e eu diria a mesma coisa - é uma potência da ação que habita antes da ação, sem o conhecimento da ação, é uma potência de encontro que habita antes do encontro, sem o conhecimento da possibilidade do encontro, ou sem a expectativa do encontro, ou o desejo do encontro.

\section{"Minha pele discretamente diz: é agora.}

É agora. É aqui que o instante é construido/habitado. É bem aqui que subvertemos juntos as hierarquias do espaço, do tempo, do corpo. É bem aqui que o tempo se arredonda, que o espaço é Niemeyer com ladeiras de Minas, que o espaço não se conclui, não se cabe, não se mede. Não se mede a desmedida do espaço. Não se mede a desmedida do tempo/curva.

É no aqui que lançamos as pedras e o jogo começa. Capturamos potências e decadências do instante. Somos farejadores, detetives, arqueólogos à procura de impulsos, interrupções, curiosidades, matérias-primas no corpo e no rastro de outro corpo-matériaobjeto-imagem-espaço-movimentopalavra. Fim." 
A gente está vivendo a vida só fazendo.

Aisthesis me deixa experimentar,

experienciar, sentir.

Treinar disponibilidades. É possivel?

Aisthesis não é método, mas é treino.

Treino do sensivel.

\section{Como usei o movimento?}

Como usei a palavra?

Como usei a sonoridade?

Como aproveitei a relação?

O que de novo conheci em mim?

O que de novo conheci no outro?

Quando me vi julgando?

Quais sensaç̋̄es observei?

A maneira como dizemos as coisas

Quando amarelei?

Quando observei o outro?

Que momento tiraram minhas

referências?

Quando percebi que atravessei uma

limitação?

O público foi agente poético? reto. $\mathrm{O}$ processo é um desvio do caminho reto.

O que é o momento que dá certo? O que é a potência na encenação do instante?

O momento de plausibilidade?

É quando o meu ato

Simples é muito bom! transformou minha ideia? 


\section{SUBVERTER - A PRATICA AISTHESIS RECLAMA NOVOS PONTOS DE VISTA SOBRE CONVENÇÕES, POIS ATUA SUBVERTENDO HÁBITOS COLETIVOS E PESSOAIS ENRIJECIDOS.}

\section{Diálogo ente Glauber e Francis}

F: Eu confirmei presença no evento.

G: Não vai!

F: Eu curti, eu curti, eu curti sua foto.

G: Finge!

F: Eu queria tanto fazer alguma coisa porque eu estou muito revoltado.

G: Toma uma colher de mel.

F: Eu tô tão revoltado, tão revoltado.

G: Isso. Mastiga um dente de alho.

F: Eu tô muito revoltado.

G: Morde uma cebola crua.

F: Eu quero muito fazer alguma coisa.

G: Dá uma lambida na latinha de vicky.

F: Eu confirmei presença no evento.

G: Pisa no cocô numa calçada de Lisboa.

F: Eu tô muito revoltado.

G: Vai no velório de alguém. Escova o dente com sabão.

F: Eu tô tão revoltado.

G: Toma banho de tênis.

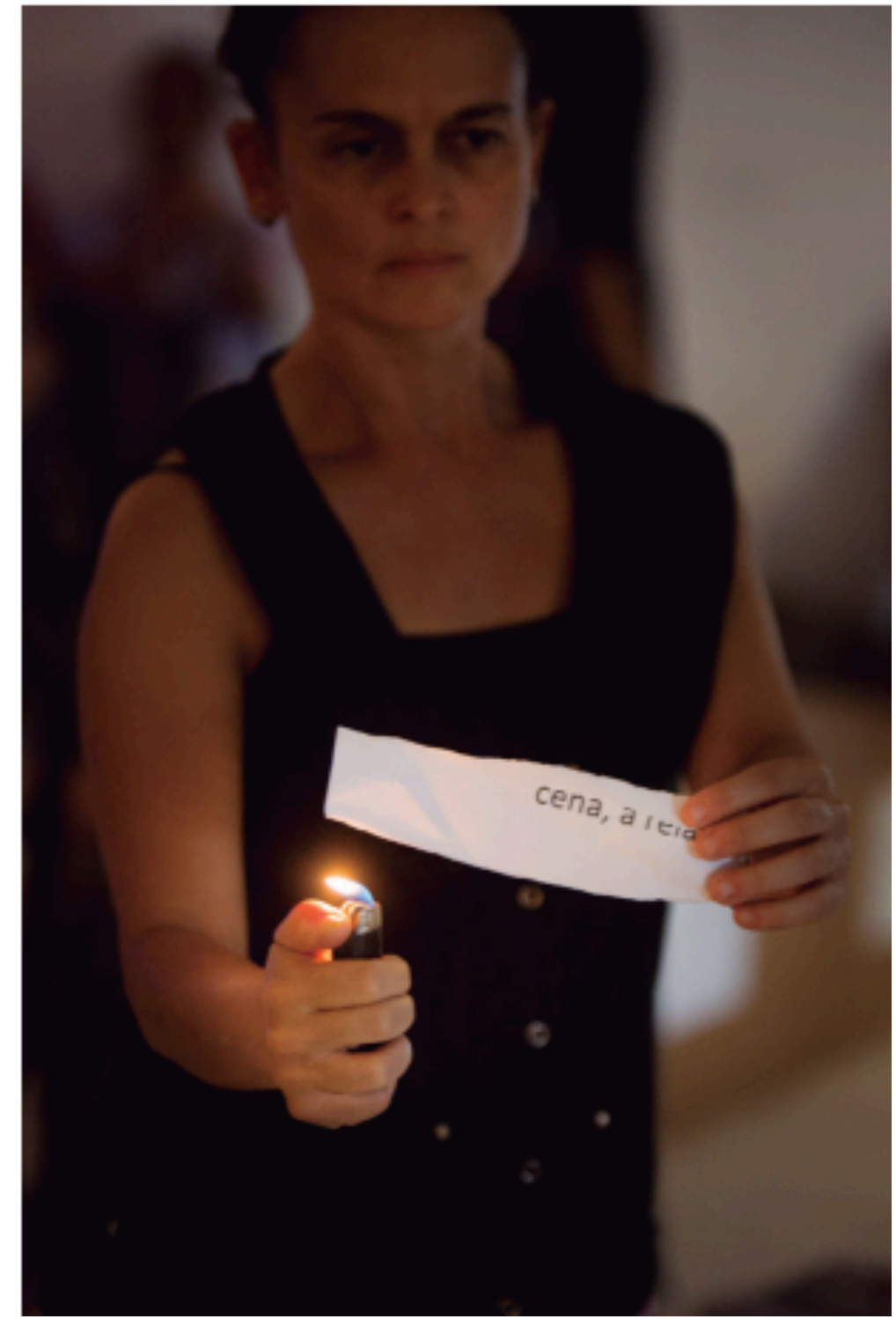




\section{VAI LÁ NOS CLÁSSICOS}

Começa lendo os clássicos. Começa lendo os clássicos. Vai lá em Ésquilo, que tem essa relaçăo vertical com o divino; vai em Sófocles, que fica mais horizontal, relação de homem pra homem; vai pra Euripedes, considerado o primeiro grande dramaturgo moderno, que falou sobre a mulher, sobre os pobres. Vai lá, vai lá nos clássicos. Lá tem tudo. As respostas estão todas nos clássicos. Vai no ĺon. Platăo escreveu f́on. Íon era um rapsodo, que ganhou um prêmio, grande prêmio; ele recitou todos os poema de Homero e ganhou um prêmio, ele era um rapsodo. Afl Platão, que quer dizer ombros largos... Vai sempre nos clássicos. Então,
Platão, fez um diálogo entre Sócrates e Íon. Sócrates com seu método indutivo, preguntando já sabendo a resposta que ele quer ouvir, vai questionar o que é a arte. Primeiro grande tratado: a arte é movida à técnica ou à expressão? É muito bom. Tem que ir nos clássicos. Tá tudo lá. Tudo já foi dito. Platão vai dizer que a arte é movida à técnica ou inspiração - aliás. Platão vai dizer que a arte é movida à inspiração. Se lon vai fazer um general de guerra ele sabe tanto sobre o trabalho de um general de guerra que ele pode de fato substituir um general de guerra quando ele estiver em guerra? Ou pode substituir um médico de tanto saber do médico, do oficio do médico, ele pode substituir um médico? ĺon fala que năo. Não!
Então, você não sabe tanto quanto um general de guerra nem tanto quanto um médico. Mas ele sabe muito bem, ele está falando e fazendo todo o ofício do general de guerra e do médico, mas mesmo assim Platão decide que a arte é movida à inspiraçăo. Porque Platăo como era? - na República, Platão tirou os artistas da cidade ideal porque têm essa capacidade de persuasão, de criar outras realidades. Então Platão diz que não. O artista é movido à inspiração, não é movido à técnica. Vai lá nos clássicos. Tá tudo lá.'

1 Texto de improvisaçălo de Kênia Dias 


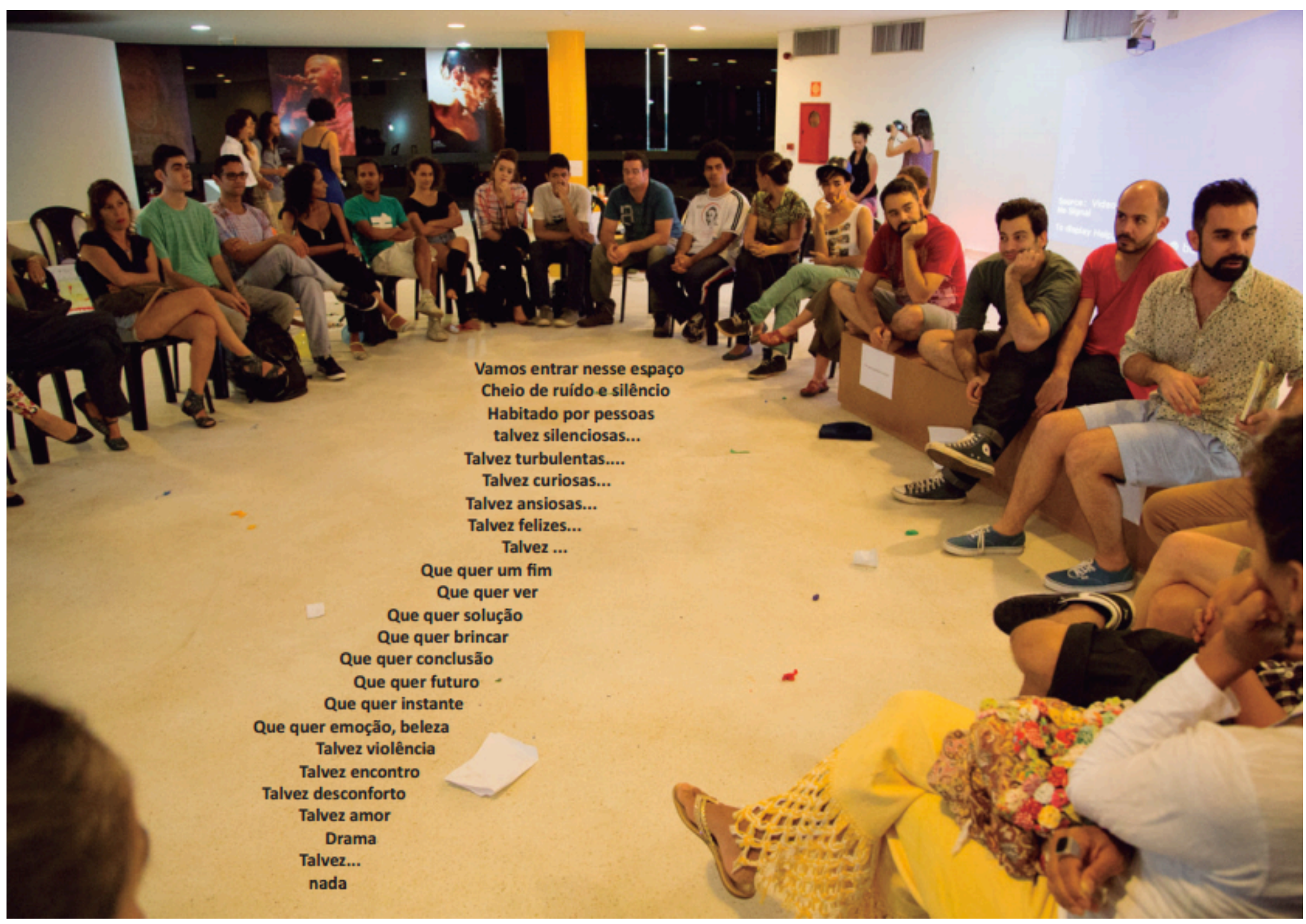




\section{REFERÊNCIAS}

ALBERTI, Verena. Literatura e Autobiografia: In: Estudos Históricos, Rio de Janeiro, vol. 4, n. 1, 1991.

BACHELARD, Gaston. A Poética do Devaneio. SP: Martins Fontes, 2009.

BARTHES, Roland. Aula. Săo Paulo: Cultrix, 2007.

BUTI, Marco. Caros artistas, pesquisem: é suficiente. ARS (Săo Paulo), SP, v. 3, n. 6, p. 88-97, jan. 2005. ISSN 2178-0447.

Disponivel em: <http://www.journals.usp.br/ars/article/view/2944/3634>.

Acesso em: 29 de junho 2017. Doi:http://dx.doi.org/10.1590/S1678-53202005000200007

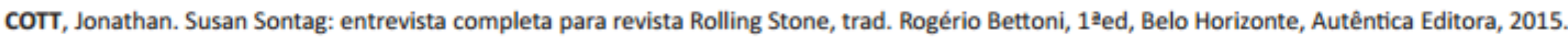

HASEMAN, Brad. In Resumos do 59 Seminário de Pesquisas em Andamento PPGAC/USP / organização:

Charles Roberto Silva; Daina Felix; Danilo Silveira; Humberto Issao Sueyoshi; Marcello Amalfi; Sofia Boito;

Umberto Cerasoli Jr; Victor de Seixas; - Săo Paulo: PPGAC-ECA/USP, 2015. v.3, n.1, 205 p.

IRWIN, Rita. A/R/Tografia, In: B. Dias \& R. Irwin (orgs.), Pesquisa Educacional Baseada em Arte: A/R/Tografia. Santa Maria: EdUFSM, 2013.

MEDEIROS, Ana Beatriz de. Aisthesis: ética, educaçăo e comunidades.Chapecó - SC, Argos, 2005.

NIETZSCHE, Friedrich Wilhelm. O nascimento da tragédia, ou Helenismo e pessimismo.Trad. J.Guinsburg, SP, Companhia das Letras, 1992.

RANCIèRE, Jacques. In: Políticas da Escrita. Rio de Janeiro: Editora34, 1995. (pp. 7-21)

\section{FOTOS DE:}

Diego Bressani, Rayssa Coe, Thiago Sabino e Christina Ruffato. 